ISSN 1936-5098

CAE Working Paper \#07-08

The Pattern and Causes of Economic Growth in India

by

Kaushik Basu

and

Annemie Maertens

April 2007 
April 5, 2007

\title{
The Pattern and Causes of Economic Growth in India
}

\author{
Kaushik Basu* and Annemie Maertens **
}

Cornell University

Ithaca

New York 14853

USA

Acknowledgements: The paper has benefited greatly from the comments and suggestions received from Alaka Basu, V. Bhaskar, Annelies Deuss, Bishnupriya Gupta, Abhijit Patnaik and two anonymous referees of this journal. We are also grateful to Charan Singh of the Reserve Bank of India for help and advice with data at several stages and to Ashokankur Datta and Namrata Gulati of the Indian Statistical Institute, New Delhi, for research assistance.

\footnotetext{
*Department of Economics. Email: kb40@ cornell.edu. (Currently, Visiting Scientist, Indian Statistical Institute, New Delhi - 110016, India)

** Department of Applied Economics and Management. Email: am445@cornell.edu
} 


\section{INTRODUCTION}

The mainspring of an economy's growth and take-off continues to puzzle economists. Even though, thanks to years of sustained research, many of the pieces of the jigsaw puzzle are in place, it remains very difficult to predict when an economy that has floundered for decades might suddenly take off. The economy, embedded as it is in politics, culture and institutions, is a sufficiently complex organism for this not to be surprising. However, growth tends to beget growth, though of course missteps can bring it to a halt. Hence, our understanding of an economy's rapid growth has to focus largely on what causes the first stirrings.

What this paper attempts is to analyze and understand the constellation of forces that have determined the growth performance of the Indian economy, including its long period of hibernation and sudden, recent show of dynamism. The first task in such an undertaking is to get the facts right. Over the last four or five years India has been getting a better press than ever before, since its independence in 1947. Is this good press really justified? If the economy is growing faster, when did the take-off occur? This is important to investigate not just to satisfy idle curiosity but to understand the various forces that may have triggered the dynamism; and that in turn is important so as to craft policies to sustain the growth and spread its spoils more evenly across the population.

Part II of the paper presents the broad macro parameters of growth of the Indian economy since its independence and also a cross country evaluation of where India stands. It then goes on to discuss the broad patterns that one discerns in these aggregative statistics pertaining to India, including the sectoral statistics, and gives a brief overview of the ongoing debate on the components of the Indian growth and the relative importance of the different policies in 1980s and 1990s. Part III tries to contribute to this debate by identifying the landmark years, and analysing the politics that occurred behind the scenes, and the extent to which it helped or hindered economic progress. Part IV looks at a critical microeconomic component of the overall growth- labor market behaviour, and is followed by a brief concluding section--Part V.

\section{GROWTH: TRENDS AND PATTERNS}

\section{II.2 Backdrop}

Thanks to a long history of data collection, the basic numbers of the Indian economy are, for a poor country, well documented. At the time of its independence, India had a literacy rate of 18\%, an investment rate of around 9\% of its GDP, life expectancy at birth of around 32 years, annual population growth rate of around $1.25 \%$, and an average annual growth rate of GDP around 3\%. In 2005-06, India had a literacy rate of around 60\%, an investment rate of around $30 \%$ of its GDP, life expectancy at birth of around 63 years, 
annual population growth rate of around 1.5\%, and an annual growth rate of GDP around $8.4 \% .^{1}$

Given that the focus of the paper is on growth, let us take a look at GDP growth and growth rate as displayed in Figure 1 and Table 1. We have graphed the natural log of the GDP, rather than the actual GDP, so that one can read the growth rate directly from the slope of the graph. A straight line represents a constant rate of growth. Table 1 presents annual averages of growth rates and averages over plan periods.

\section{Figure 1 \\ Ln GDP [at constant prices], 1950-2005}

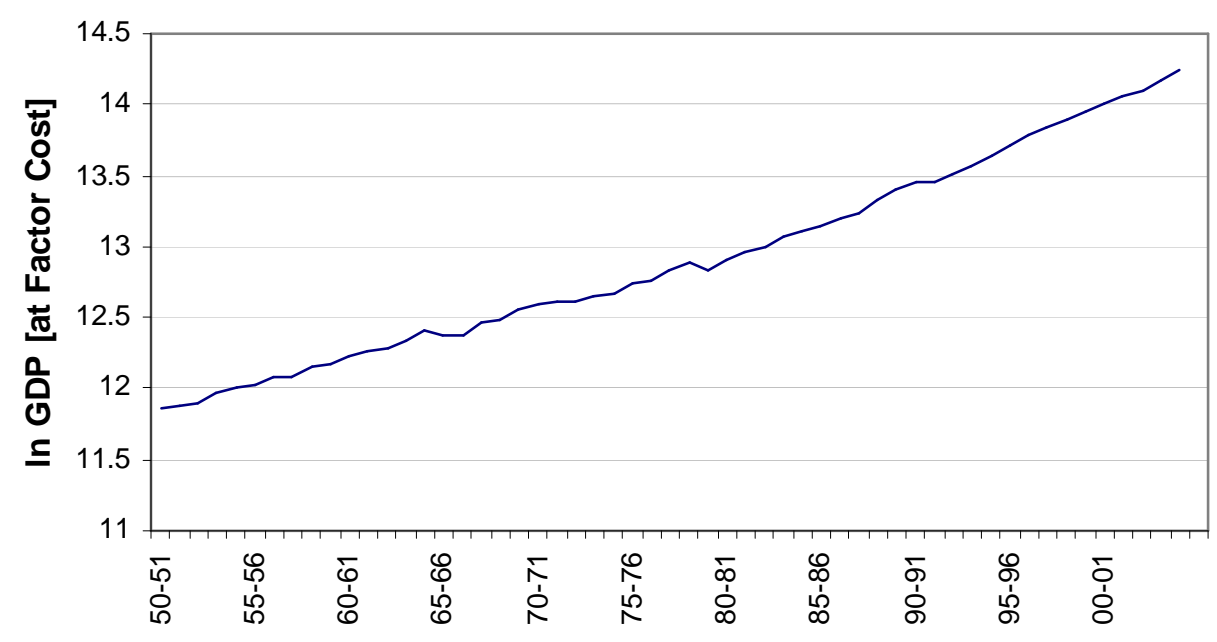

Source: Handbook of Statistics on the Indian Economy. 2006. Reserve Bank of India (Table 2 - old series base: 1993-94).

Without going into any detailed analysis as yet, by just eyeballing the data in Table 1, it seems that the rate of growth in the 1950s, 60s and 70s has been fluctuating around $3.5 \%$ per annum, the so-called "Hindu rate of growth"2. With an average annual rate of population growth of around $1.9 \%$, this results in an average annual growth in per-capita growth rate GDP of around 1.6\%. From the mid 1970s-80s onwards, the rate of growth exhibits an upward trend, averaging around 6\% for the period 1980-2005.

\footnotetext{
${ }^{1}$ Sources, respectively: Selected Education Statistics (age 15 and above), Ministry of Human Resource Development, from Indiastat; Table 1; Age-Group Wise Expectation of Life in India, Ministry of Health and Family Welfare, from Indiastat; Dyson, Cassen and Visaria (2004) Table 2.1. p 20; Table 1; Estimated literacy rate age 15 and above of UNESCO; Table 1; World Development Indicators 2006, World Bank; Dyson, Cassen and Visaria (2004) Table 2.1. p 20; Table 1.

${ }^{2}$ Hindu rate of growth is the tongue-in-cheek expression, coined by the Indian economist, the late Raj Krishna, to capture the frustrations India's planners faced with growth. No matter what they did, growth seemed, invariably, to revert back to $3.5 \%$ per annum, almost as if this magic figure was written in the land's scriptures. The possibility of Hinduism having something to do with economic growth was earlier suggested by B.P. R. Vithal.
} 
Table 1

Annual Growth Rate of Real GDP and Gross Capital Formation, 1950-2006

\begin{tabular}{|c|c|c|c|c|c|}
\hline Year & $\begin{array}{l}\text { Annual Growth } \\
\text { Rate of GDP at } \\
\text { Factor Costs }\end{array}$ & $\begin{array}{c}\text { Gross } \\
\text { Domestic } \\
\text { Capital } \\
\text { Formation (\% } \\
\text { of GDP at } \\
\text { Factor Cost) }\end{array}$ & Year & $\begin{array}{c}\text { Annual Growth } \\
\text { Rate of GDP at } \\
\text { Factor Costs }\end{array}$ & $\begin{array}{c}\text { Gross } \\
\text { Domestic } \\
\text { Capital } \\
\text { Formation (\% } \\
\text { of GDP at } \\
\text { Factor Cost) }\end{array}$ \\
\hline $1950-51$ & & 9.07 & $1980-81$ & 7.2 & 22.45 \\
\hline $1951-52$ & 2.3 & 11.59 & 1981-82 & 6 & 22.34 \\
\hline $1952-53$ & 2.8 & 8.32 & $1982-83$ & 3.1 & 21.79 \\
\hline $1953-54$ & 6.1 & 8.08 & $1983-84$ & 7.7 & 20.69 \\
\hline $1954-55$ & 4.2 & 10.04 & $1984-85$ & 4.3 & 22.16 \\
\hline $1955-56$ & 2.6 & 13.64 & Average & 5.6 & \\
\hline Average & 3.6 & & $1985-86$ & 4.5 & 24.2 \\
\hline $1956-57$ & 5.7 & 15.76 & 1986-87 & 4.3 & 23.47 \\
\hline $1957-58$ & -1.2 & 14.73 & $1987-88$ & 3.8 & 25.23 \\
\hline $1958-59$ & 7.6 & 12.64 & $1988-89$ & 10.5 & 26.48 \\
\hline $1959-60$ & 2.2 & 13.36 & $1989-90$ & 6.7 & 27.23 \\
\hline Average & 3.5 & & Average & 5.9 & \\
\hline $1960-61$ & 7.1 & 15.23 & $1990-91$ & 5.6 & 29.27 \\
\hline $1961-62$ & 3.1 & 14.18 & 1991-92 & 1.3 & 25 \\
\hline $1962-63$ & 2.1 & 15.95 & 1992-93 & 5.1 & 26.25 \\
\hline 1963-64 & 5.1 & 15.31 & 1993-94 & 5.9 & 25.39 \\
\hline $1964-65$ & 7.6 & 15.26 & $1994-95$ & 7.3 & 28.72 \\
\hline Average & 5.0 & & Average & 5.0 & \\
\hline $1965-66$ & -3.7 & 17.47 & $1995-96$ & 7.3 & 29.77 \\
\hline $1966-67$ & 1 & 18.19 & 1996-97 & 7.8 & 26.94 \\
\hline $1967-68$ & 8.1 & 15.17 & $1997-98$ & 4.8 & 26.94 \\
\hline $1968-69$ & 2.6 & 14.23 & 1998-99 & 6.5 & 24.59 \\
\hline $1969-70$ & 6.5 & 15.99 & 1999-00 & 6.1 & 28.43 \\
\hline Average & 2.8 & & Average & 6.5 & \\
\hline $1970-71$ & 5 & 16.68 & $2000-01$ & 4.4 & 26.37 \\
\hline $1971-72$ & 1 & 17.46 & 2001-02 & 5.8 & 24.97 \\
\hline $1972-73$ & -0.3 & 16.53 & $2002-03$ & 3.8 & 27.51 \\
\hline 1973-74 & 4.6 & 18.81 & 2003-04 & 8.5 & 29.57 \\
\hline $1974-75$ & 1.2 & 18.28 & 2004-05 & 7.5 & 33.04 \\
\hline Average & 2.3 & & Average & 6.0 & \\
\hline $1975-76$ & 9 & 18.79 & 2005-06 & $9.0 *$ & \\
\hline 1976-77 & 1.2 & 19.78 & 2006-07 & $9.2^{*}$ & \\
\hline $1977-78$ & 7.5 & 20.11 & & & \\
\hline $1978-79$ & 5.5 & 23.85 & & & \\
\hline \multirow[t]{2}{*}{$1979-80$} & -5.2 & 22.85 & & & \\
\hline & 3.5 & & & & \\
\hline \multicolumn{6}{|c|}{ Per 5 Year Plan Periods } \\
\hline I. 1951-56 & 3.6 & & VI. 1980-85 & 5.6 & \\
\hline 1I. 1956-61 & 4.2 & & VII. 1985-90 & 6.0 & \\
\hline III. 1961-66 & 2.8 & & VIII. 1992-97 & 6.7 & \\
\hline IV. 1969-74 & 3.3 & & IX. 1997-02 & 5.5 & \\
\hline V. 1974-79 & 4.8 & & & & \\
\hline
\end{tabular}

Source: Handbook of Statistics on the Indian Economy. 2006. Reserve Bank of India (Table 1 and Table 237). Notes: Up to 1999-00 old series (base: 1993-94). From 2000-01 onwards new series (base: 19992000). Averages: authors' own calculations.

*Latest estimates, released by the Ministry of Finance, Economic Survey 2006-07 
To get a basic idea of the absolute numbers involved, Table 2 gives the size of the Indian population, the real GDP (at market prices) and the real GDP per capita (at market prices). The key difference between the GDP at factor costs and the GDP at market prices is that the latter includes indirect taxes net of subsidies. As the latter is considered a better measure of the standard of living, we have opted to report the absolute figures of the GDP and GDP per capita at market prices.

Table 2

Population, GDP and GDP per Capita at Market Prices, Selected Years

\begin{tabular}{cccc}
\hline Year & $\begin{array}{c}\text { Population }(\text { in } \\
\text { millions }\end{array}$ & $\begin{array}{c}\text { GDP (in millions } \\
\text { constant 2000 US\$) }\end{array}$ & $\begin{array}{c}\text { GDP per Capita } \\
\text { (constant 2000 US\$) }\end{array}$ \\
\hline 1960 & 435 & 76,283 & 175 \\
1965 & 487 & 91,054 & 187 \\
1970 & 548 & 113,606 & 207 \\
1975 & 613 & 130,913 & 213 \\
1980 & 687 & 152,621 & 222 \\
1985 & 765 & 198,167 & 259 \\
1990 & 850 & 268,023 & 316 \\
1995 & 932 & 345,394 & 371 \\
2000 & 1,016 & 457,377 & 450 \\
2005 & 1,095 & 641,926 & 586 \\
\hline
\end{tabular}

Source: World Development Indicators 2006. World Bank

From Table 2 it is clear that while the Indian population has more than doubled since the 1960s, GDP has increased more than eightfold since then. As the population figures for India are based on projections from Census of India data ${ }^{3}$, we have opted not to show the entire time series for population or GDP per capita.

To conclude this introduction, let us ask one more factual question, how has India done vis-à-vis other nations, especially other developing countries? Has it really done better or is it simply the fact of a large country beginning to grow that has caught the media's attention and imagination?

In order to answer this question we assembled the Purchasing Power Parity (PPP)corrected national income and per capita national income data of the World Bank for a 109 countries. ${ }^{4}$ There was a trade-off involved. As one goes further back, data, especially when we want it PPP-corrected, gets sparse and more and more countries have to be left out. We chose to go back to 1975, when the PPP corrected data became available for the first time. There are 109 countries for which data are available without break from that

\footnotetext{
${ }^{3}$ The first census of India was carried out throughout the 1860 s and completed in 1871 . Since then there have been 13 more censuses, one per decade, the latest one being the 2001 census.

${ }^{4}$ The PPP corrected GDP takes into account the difference in prices of goods and services between countries. As the exchange rate only takes into account the differences in tradable goods and services and several countries have non-market based exchange rate determination, it is arguable that the PPP allows us to make more meaningful comparisons of standards of living across countries.
} 
year to current times. For each year, since 1975, we ranked these 109 countries based on PPP-corrected GDP and per capita GDP.

From this assembled data set (not shown here) it is clear that not only has the country done better over time vis-à-vis itself but even in comparison to others. In terms of GDP per capita, India ranked $90^{\text {th }}$ among these nations in 1975 . The rank fluctuated a little between 1975 and 1982, falling to $93^{\text {rd }}$ and rising again to $90^{\text {th }}$. From 1982 onwards there has been a steady and monotonic improvement, with India's per capita GDP (PPP corrected), rising to $75^{\text {th }}$ rank in 2004 . There are two or three countries that did better than India over this period, the most notable being China, which was $108^{\text {th }}$ among the 109 countries in 1975 but had risen to a rank of $58^{\text {th }}$ by 2004 . But, as follows from the fact of rank improvement, India crossed over numerous nations during the last three decades.

In terms of GDP ranking the improvement has also been marked, though this is tempered by the fact that some of the poorer economies have had a faster growth of population, especially over the last two decades. In 1985 India's PPP-corrected GDP was the $8^{\text {th }}$ largest in the world, and by 2004 it was the fourth largest, with only the USA, China and Japan ahead. ${ }^{5}$

Despite this rank improvement, India and South Asia in general are still among the poorest regions in the world (see Table 3). Indeed, a quick look at one of the most important development indicators, the population below the poverty line shows us that despite the decline in poverty headcount ratio, from $55 \%$ in $1973-74$ to $29 \%$ in $1998-99$, India still accounts for a large absolute number of poor people, close to 30 million in $2000 .^{6}$

Table 3

GDP per Capita (2000 constant dollars), Selected Comparisons

\begin{tabular}{lccccccc}
\hline & 1965 & 1970 & 1980 & 1990 & 1995 & 2000 & 2004 \\
\hline India & 187 & 207 & 222 & 316 & 371 & 450 & 538 \\
Sub-Saharan Africa & 485 & 536 & 577 & 520 & 484 & 504 & 537 \\
South Asia & 197 & 220 & 234 & 326 & 377 & 446 & 522 \\
East Asia and Pacific & 145 & 176 & 273 & 481 & 735 & 952 & 1254 \\
Latin America and Caribbean & 2276 & 2616 & 3568 & 3262 & 3555 & 3854 & 3906 \\
World & 2843 & 3316 & 3974 & 4555 & 4748 & 5237 & 5516 \\
\hline
\end{tabular}

Source: World Development Indicators 2006, World Bank. Note: The East-Asia and Pacific, Latin America and Caribbean aggregates do not contain the High Income countries.

This change in India's growth rate and improved economic performance vis-à-vis other nations triggered off a change in global perception not just in academic writing, but in the

\footnotetext{
${ }^{5}$ If India's rank is measured in GDP (constant 2000 international dollars), India ranks 13.

${ }^{6}$ Sources: Handbook of Statistics of the Indian Economy 2005-2006. Table 172. Reserve Bank of India and NSS $55^{\text {th }}$ Round Official Estimates. Note that the measurement of poverty has been a hotly debated subject especially since the $55^{\text {th }}$ round of the National Sample Survey tried to change the reference period of household consumption (see Deaton and Drèze, 2002; Himanshu and Sen, 2005; Lancaster and Ray, 2005; Subramanian, 2006, Chapter 10).
} 
media and popular business publications, that India was a newly emerging and dynamic economy and, in very recent years, it has been repeatedly compared to China ${ }^{7}$. This was unthinkable to most India watchers even a decade ago. This popular celebration of the economy gives rise to a host of questions. While the strengthening of the growth rate is beyond doubt, the recorded overall growth rate is not the only indicator one uses to judge an economy and so the question arises as to whether the fundamentals are as strong as the media make them out to be. What are the strengths and weaknesses of the economy? Is there reason to expect that the growth will be sustained? What are the right policies for sustaining the high growth and spreading its spoils better among the population? Even though growth is higher, can we pin down when exactly the breaks occurred?

\section{II.2 Growth Patterns and Hypotheses}

Turning to details of the growth performance, let us take another look at the growth rate of the GDP in Figure 2 and Table 1. Observe that the spikes in annual growth rates have not changed very much over the years; it is the downturns that have become less severe and frequent. Before 1980, there were four years when the GDP recorded negative growth rates: 1957-58, 65-66, 72-73, and 79-80. Since 1980 never has the economy, as measured by GDP, shrunk in any year, though per capita GDP fell once-during 199091-caused by the first Gulf War and a sharp decline in remittances and exports. GDP grew slowly that year but by less than the population growth.

Due to the huge amount of noise the trends are not too evident to the naked eye. But once we smoothen out these annual fluctuations and look, instead, at averages of several years of growth (see Table 1), a pattern emerges. The average growth holds steady till about the mid-seventies and then, somewhere after that, it begins to move up and that upward incline has persisted till current times. This is corroborated by the average, annual growth rate figures for each of the five-year plan periods. Average annual growth broke the 5\% mark for the first time during the Fifth Plan period, 1974-79, and has never dropped below that. The sharp spike occurred during the Eighth Plan period, 1992-97, when annual growth averaged $6.7 \%$. All the portents are that during the Tenth Plan period the economy will grow at close to $8 \%$ per annum. Given that India's population growth rate is much slower than what it used to be three or four decades ago (1.5\% in 2004-05 versus $2.22 \%$ in $1971-72^{8}$ ) this means that the rise in per capita income growth rate from the sixties and seventies to current times has been even more marked.

More formal evidence that the GDP growth series exhibits a structural break at the end of the seventies - beginning of the 1980s can be found in Virmani (1997, 2004a), Rodrik and Subramanian (2004b), Wallack (2003), and Balakrishnan and Parameswaran (2006). The latter, for instance, use a regression based least squares approach that does not arbitrarily partition the data according to pre-selected break points and identify 1978-79 as a structural break year for the GDP growth series. These authors challenged the standard view held in the 1990s by the public and a large majority of the economists that the policy reforms of the early 1990s had caused or played a major role in the growth acceleration (views held by for instance Ahluwalia, 2002; Srinivasan and Tendulkar,

\footnotetext{
${ }^{7}$ This changing perception is cited and discussed in Basu (2006b).

${ }^{8}$ Source: Dyson, Cassen and Visaria (2004) Table 2.1. p 20.
} 
2003). A new view emerged, lead by Rodrik and Subramanian (2004a, 2004b), Panagariya (2004) and Virmani (2004a), De Long (2003), and Williamson and Zagha (2002), that the surge in growth rate in India happened around 1980 and could therefore not be attributed entirely to the new economic policies of the early 1990s.

Figure 2

Growth Rate of GDP in India, 1950-2006

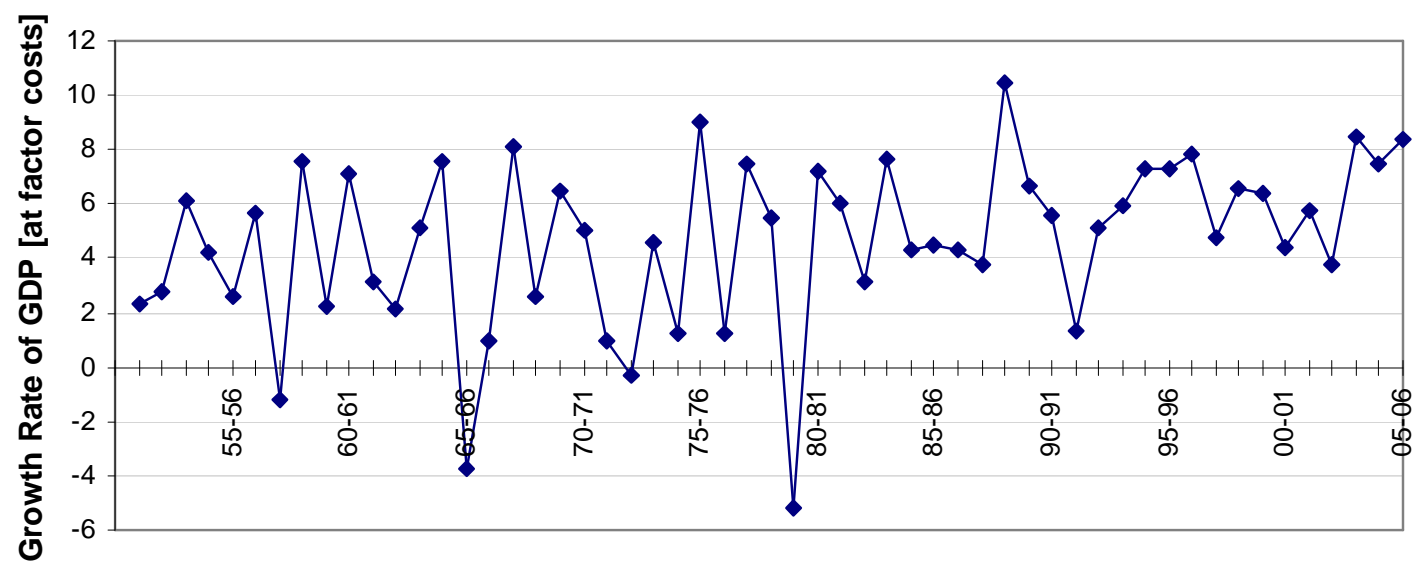

Source: Table 1

While it is difficult to dispute that a rise in growth rate took place before 90s, it is possible to argue that there was further acceleration after the nineties reforms, which can be attributed to the reforms. Further, we are inclined to argue, as indeed some others have done that the growth in the 80s was not of a sustainable nature, since it relied excessively on deficit financing and excessive foreign borrowing (Basu, 2004; Panagariya, 2004; Srinivasan, 2005).

To further understand this debate and the components of the post-80s growth let us take a look at the results of the growth accounting exercise of Bosworth et al. (2007). The objective of growth accounting is to decompose the economic growth rate of a country into contributions of different factors. Assuming a certain aggregate production function and competitive markets, the method identifies the contribution of the different factors (such as labor and physical capital) and a residual, called the Total Factor Productivity (TFP). ${ }^{9}$ Changes in the TFP represent changes in efficiency and/or changes in production technology. Table 4 shows the results of this exercise.

\footnotetext{
${ }^{9}$ Thereby hinting at the main critique of this approach: that total factor productivity is a residual and as such incorporates also all kinds of shocks, such as political turmoil, external shifts and measurement errors.
} 
Table 4

Contributions to Growth (in Annual Percentage Rate of Change)

\begin{tabular}{cccccccc}
\hline $\begin{array}{c}\text { Selected } \\
\text { periods }\end{array}$ & Output & Employment & $\begin{array}{c}\text { Output } \\
\text { per Worker }\end{array}$ & $\begin{array}{c}\text { Physical } \\
\text { Capital }\end{array}$ & $\begin{array}{c}\text { Contribution of } \\
\text { Land }\end{array}$ & $\begin{array}{c}\text { Eductotion } \\
\text { Productivity }\end{array}$ \\
\hline $1960-73$ & 3.3 & 2 & 1.3 & 1.1 & -0.2 & 0.1 & 0.2 \\
$1973-83$ & 4.2 & 2.4 & 1.8 & 0.9 & -0.2 & 0.3 & 0.6 \\
$1983-93$ & 5 & 2.1 & 2.9 & 0.9 & -0.1 & 0.3 & 1.7 \\
$1993-99$ & 7 & 1.2 & 5.8 & 2.4 & -0.1 & 0.4 & 2.8 \\
$1999-04$ & 6 & 2.4 & 3.6 & 1.2 & 0.1 & 0.4 & 2 \\
\hline $1960-04$ & 4.7 & 2 & 2.6 & 1.2 & -0.1 & 0.3 & 1.2 \\
$1960-80$ & 3.4 & 2.2 & 1.3 & 1 & -0.2 & 0.2 & 0.2 \\
$1980-04$ & 5.8 & 1.9 & 3.8 & 1.4 & 0 & 0.4 & 2 \\
\hline
\end{tabular}

Source: Bosworth et al. (2007): Table 3

Table 4 shows that the pre-1980 growth is mainly associated with an increase in factors while the post 1980 growth is associated with an increase in factors, but more importantly an increase in TFP. ${ }^{10}$ Looking at the entire time series, they conclude that the TFP growth took off around the early 80s, and has shown an increasing trend since then. This finding is consistent with other studies on TFP growth (Rodrik and Subramanian 2004b, Virmani 2004b). Despite the large structural change in the economy (see Table 5), this increase in TFP, according to these authors, mainly reflects an improvement of the performance of the individual sectors rather than a re-allocation of resources from low-productivity sectors (agriculture) to higher productivity sectors (manufacturing and services). ${ }^{11}$

Table 5

Percentage of GDP (at factor costs) by Industry of Origin

\begin{tabular}{cccccc}
\hline Year & $\begin{array}{c}\text { Agriculture, } \\
\text { forestry, } \\
\text { fishing mining } \\
\text { and quarrying }\end{array}$ & $\begin{array}{c}\text { Manufacturing, } \\
\text { construction, } \\
\text { electricity, gas } \\
\text { and water } \\
\text { supply }\end{array}$ & $\begin{array}{c}\text { Trade, hotel, } \\
\text { transport and } \\
\text { communication }\end{array}$ & $\begin{array}{c}\text { Financing, } \\
\text { insurance, real } \\
\text { estate and } \\
\text { business } \\
\text { services }\end{array}$ & $\begin{array}{c}\text { Public } \\
\text { administration } \\
\text { and defence } \\
\text { and other } \\
\text { services }\end{array}$ \\
\hline $1950-51$ & 59 & 13 & 12 & 7 & 9 \\
$1960-61$ & 55 & 17 & 14 & 6 & 9 \\
$1970-71$ & 48 & 20 & 16 & 6 & 11 \\
$1980-81$ & 40 & 22 & 18 & 7 & 12 \\
$1990-91$ & 35 & 24 & 19 & 10 & 12 \\
$2000-01$ & 27 & 24 & 22 & 13 & 15 \\
$2005-06$ & 23 & 24 & 25 & 13 & 14 \\
\hline
\end{tabular}

Source: Economic Survey 2005-2006. Ministry of Finance, Table 1.3

\footnotetext{
${ }^{10}$ Other studies confirm this general trend (see for instance Dholakia, 2002). A more detailed discussion can be found in Virmani (2004b).

${ }^{11}$ According to Rodrik and Subramanian (2004b) a structural shift can only explain $10 \%$ of the TFP growth.
} 
But how did this sudden surge in TFP come about? Rodrik and Subramanian (2004b) suggest that even though the reforms of the 80s, which consisted of industrial delicensing measures, lowering of tax rates, limited import liberalization, and anti-labor policies, were not substantial, this small trigger could have elicited a large response in TFP because India was below its production possibility frontier. The increases in TFP would in that case just be a reflection of the move towards the frontier rather than a shift of the frontier itself. ${ }^{12}$ As a whole they see an attitudinal shift towards "pro-business" (in contrast to the "pro-market" policies of the 90s) as crucial in explaining the surge in the aggregate growth rate and TFP. ${ }^{13}$ They share this view with other authors, like Panagariya (2004), who see the switch from a 'positive' list approach, where restrictions are the rule and few exceptions are allowed, in 1980s towards a 'negative' list approach in the 1990 s as crucial.

Let's now turn to the disaggregate figures of growth and TFP. Beginning with the primary sector, from Table 6 (column 1) it is clear that the growth rate of this sector has been extremely volatile. The (arithmetic) average annual growth rate of the entire series is $5.5 \%$ and the standard deviation is $3.8 \%$. Despite the irregular nature of this time series, Balakrishnan and Parameswaran (2006) were able to discern a structural break, namely a positive break around 1964-65. Notably, this break is situated slightly before the onset of the Green Revolution (around 1967-68), which in India mainly consisted of the spread of genetically modified rice and wheat varieties. According to them, this structural break "may owe something to the steady expansion in irrigated area in the decade and half preceding the mid-sixties". ${ }^{14}$ Indeed, given the significance of agriculture as a share of GDP in the 1950s-1980s, it seems that a good or a bad year in terms of rains can have a large impact on the overall growth rate. Consider for example the GDP growth rates of the good years 1958-59, 1967-68, and 1988-89 in Table 6. Virmani (2004a) however contests this conventional wisdom and argues that there is no change in the impact of rainfall fluctuations on the Indian economy during the last 50 years. As far as TFP is concerned, Bosworth et al. (2007) show that, taking 1960 as the index year (1960 $=1$ ), the growth of TFP in the agriculture sector fluctuates around the index 1 up to the mid to late $80 \mathrm{~s}$, after which an increasing trend can be discerned. In figures, they find that the TFP growth changes from $-0.2 \%$ per year during $1960-73$ to $0.9 \%$ per year during 1973-83, and to $1.2 \%$ during 1983-99.

Despite the fact that the growth figures of the last few years do not seem structurally different than the growth figures of the previous decades, there is talk of an agrarian crisis in India. This is caused by the declining public investments in agriculture (a trend which started in the early 80s), the decline in agriculture as a share of the GDP associated with relatively little reallocation of employment (the primary sector contributes $20 \%$ of the GDP but has a share of $60 \%$ of the employment), the fact that poverty in India is a

\footnotetext{
${ }^{12}$ The reforms of the 80s are extensively discussed by, among others, Kohli (2006a), Virmani (2004b) and Panagariya (2004).

${ }^{13}$ Rodrik and Subramanian (2004b) claim that they provide evidence for this attitudinal shift by the government in the early 1980s that favored the interests of existing businesses rather than new entrants or consumers. This evidence has been contested by Srinivasan (2005).

${ }^{14}$ The current gross irrigated area is $40 \%$ of the cultivated area. This area has increased a lot over the last 40 years (see: Agricultural Statistics at a Glance, August 2004, Table 14.2).
} 
predominantly rural phenomenon and the rise in farmer suicides, mainly in the states of Karnataka, Andhra Pradesh and Maharashtra (Vaidyanathan, 2006).

Turning to industry, let us first look at the industry figures in column 2 of Tables 5 and 6 . The share of the industrial sector has increased over the last 50 years from $13 \%$ at the time of independence to $24 \%$. As such the structure of the economy is nowadays of a very different nature in India than in China where industry represents nearly $50 \%$ of the economy. The time series in column 2 , Table 6 , which seems at first sight quite volatile, has an (arithmetic) average of approximately $6 \%$ and a standard deviation of $2.9 \%$. According to Balakrishnan and Parameswaran (2006), the manufacturing series exhibits three structural breaks. The first negative structural break is in the mid-sixties. The second positive structural break is in 1982-83, and the third negative structural break is in 1994-95. They interpret these figures as evidence against the hypothesis that manufacturing had led the acceleration in the GDP growth rate at the beginning of the 80s. Virmani (2004a) however comes to the exact opposite conclusion: "this (analysis) shows that the growth rate of manufacturing accelerated after 1980-81. This contributed to the acceleration of the rate of growth of GDP from 1981". And the debate does not end there. According to Bosworth et al. (2007), the TFP growth of industry is slowing down, not accelerating, during the post reform period. They conclude that "these results are disappointing in light of the attention that has been devoted to the on-going liberalization of the trade and regulatory regimes for goods production." Their conclusions related to manufacturing are very similar to the ones for industry as a whole. They, among others, thereby provide counter-evidence to the studies of Ahluwalia (1995) and Unel (2003) who concluded that manufacturing experienced a surge of productivity in the 1980s. Goldar and Mitra (2002) take the more skeptical line that these differences in findings can be attributed to a variety of measurement issues.

Finally, let us take a look at the service sector figures in the remaining columns of Tables 5 and 6 . Table 6 shows that, since the 80s, the services have shown a more consistent higher annual growth rate than the industrial and the agricultural sectors of the economy. Bosworth et al. (2007) show that according to their growth accounting analysis this increase in growth rate is mainly due to an increase in TFP. This is rather puzzling as services are normally considered as an area of limited productivity growth. They suggest a number of explanations for this phenomenon such as an incorrect measurement of the prices in the service industry. Srinivasan (2005) even suggests that the higher wages in the public sector might be driving a spurious increasing TFP. This is clearly an area which needs further research.

Given the predominance of the services in the Indian economy (see Table 5), namely $52 \%$ of the GDP in 2005-06, several authors have concluded that this sector is driving the current growth India witnesses. According to the analysis of Balakrishnan and Parameswaran (2006), services have led the acceleration in the growth of GDP in India in the late seventies - early eighties (see, also, Babu, 2005). In this regard also, the growth in India is of a very different nature from the growth in China, where services contribute only $33.2 \%$ to the GDP (Panagariya, 2004). As only 23\% of the population is employed in India's service sector and the growth in employment in this sector has been low, many scholars have concluded that India is caught in the groove of 'jobless growth'. While the 
growth in employment need not match the growth in each the sector, the discrepancy between the contribution of the primary sector to the GDP (20\%) and its share in the workforce ( $60 \%$ of the population) is indeed worrisome.

Table 6

Annual Growth Rate of Real GDP at Factor Cost by Industry of Origin

\begin{tabular}{|c|c|c|c|c|c|}
\hline & $\begin{array}{l}\text { Agriculture, } \\
\text { forestry, } \\
\text { fishing, mining } \\
\text { and quarrying }\end{array}$ & $\begin{array}{l}\text { Manufacturing, } \\
\text { construction, } \\
\text { electricity, gas } \\
\text { and water } \\
\text { supply }\end{array}$ & $\begin{array}{l}\text { Trade, hotels, } \\
\text { transport and } \\
\text { communication }\end{array}$ & $\begin{array}{l}\text { Financing, } \\
\text { insurance, real } \\
\text { estate, and } \\
\text { business } \\
\text { services }\end{array}$ & $\begin{array}{l}\text { Public } \\
\text { administration, } \\
\text { defense and } \\
\text { other services }\end{array}$ \\
\hline $1951-52$ & 1.8 & 4.5 & 2.7 & 2.3 & 3 \\
\hline $1952-53$ & 3.1 & 0.1 & 3.2 & 4.2 & 2.1 \\
\hline $1953-54$ & 7.5 & 6.4 & 3.7 & 1.4 & 3.1 \\
\hline $1954-55$ & 3 & 8.6 & 6.4 & 3.7 & 3.6 \\
\hline $1955-56$ & -0.8 & 11.2 & 7.3 & 4 & 3.1 \\
\hline Average & 2.9 & 6.1 & 4.6 & 3.1 & 3.0 \\
\hline $1956-57$ & 5.4 & 8.8 & 7.4 & 1.6 & 3.8 \\
\hline $1957-58$ & -4.2 & -1 & 3.3 & 3.8 & 4.5 \\
\hline $1958-59$ & 9.9 & 7.1 & 5.1 & 2.8 & 4.1 \\
\hline $1959-60$ & -0.8 & 7.1 & 6.3 & 3.8 & 4.3 \\
\hline Average & 2.5 & 5.6 & 5.3 & 3.0 & 3.9 \\
\hline $1960-61$ & 7.0 & 10.5 & 8.5 & 2.1 & 4.9 \\
\hline $1961-62$ & 0.3 & 7.2 & 6.5 & 4.3 & 4.7 \\
\hline $1962-63$ & -1.5 & 6.4 & 6.0 & 3.4 & 7.1 \\
\hline $1963-64$ & 2.4 & 10.6 & 7.1 & 3.1 & 6.6 \\
\hline $1964-65$ & 8.9 & 7.3 & 6.7 & 2.7 & 6.6 \\
\hline Average & 3.3 & 8.4 & 7.0 & 3.1 & 6.0 \\
\hline $1965-66$ & -10.2 & 3.0 & 2.0 & 3.0 & 4.0 \\
\hline $1966-67$ & -1.3 & 3.4 & 2.6 & 1.8 & 4.6 \\
\hline $1967-68$ & 14.3 & 3.1 & 4.4 & 2.7 & 3.9 \\
\hline $1968-69$ & 0.0 & 5.2 & 4.6 & 4.9 & 4.5 \\
\hline $1969-70$ & 6.4 & 8.1 & 5.4 & 4.2 & 5.5 \\
\hline Average & 1.5 & 4.5 & 3.8 & 3.3 & 4.5 \\
\hline $1970-71$ & 6.5 & 1.8 & 4.8 & 4.2 & 5.5 \\
\hline $1971-72$ & -1.7 & 2.7 & 2.3 & 5.2 & 4.5 \\
\hline $1972-73$ & -4.6 & 3.5 & 2.5 & 3.9 & 3.3 \\
\hline $1973-74$ & 6.9 & 1.1 & 4.2 & 2.4 & 2.6 \\
\hline $1974-75$ & -1.3 & 1.3 & 6.2 & -0.3 & 4.7 \\
\hline Average & 1.1 & 2.1 & 4.0 & 3.1 & 4.1 \\
\hline $1975-76$ & 12.9 & 6.1 & 9.0 & 6.9 & 3.5 \\
\hline $1976-77$ & -5.4 & 9.3 & 4.6 & 7.9 & 2.8 \\
\hline $1977-78$ & 9.7 & 7.2 & 6.4 & 4.9 & 2.7 \\
\hline $1978-79$ & 2.3 & 8.0 & 8.1 & 7.1 & 4.3 \\
\hline $1979-80$ & -12.2 & -3.4 & -0.4 & 1.0 & 7.3 \\
\hline Average & 1.0 & 5.3 & 5.5 & 5.5 & 4.1 \\
\hline $1980-81$ & 12.9 & 4.0 & 5.7 & 1.9 & 4.1 \\
\hline $1981-82$ & 5.7 & 7.4 & 6.2 & 8.3 & 2.6 \\
\hline $1982-83$ & 0.0 & 2.9 & 4.6 & 10.4 & 8.0 \\
\hline
\end{tabular}




\begin{tabular}{|c|c|c|c|c|c|}
\hline $1983-84$ & 9.1 & 8.7 & 4.9 & 10.0 & 3.9 \\
\hline $1984-85$ & 1.5 & 6.2 & 5.1 & 8.5 & 6.8 \\
\hline Average & 5.7 & 5.8 & 5.3 & 7.8 & 5.1 \\
\hline $1985-86$ & 1.0 & 4.7 & 7.9 & 10.2 & 6.5 \\
\hline $1986-87$ & 0.2 & 6.2 & 5.9 & 11.3 & 7.0 \\
\hline $1987-88$ & -1.0 & 7.0 & 5.2 & 8.4 & 7.2 \\
\hline $1988-89$ & 15.4 & 8.6 & 6.0 & 11.4 & 6.4 \\
\hline $1989-90$ & 1.9 & 10.7 & 7.4 & 12.6 & 8.3 \\
\hline Average & 3.3 & 7.4 & 6.5 & 10.8 & 7.1 \\
\hline 1990-91 & 4.6 & 7.4 & 4.9 & 7.7 & 4.1 \\
\hline 1991-92 & -1.1 & -1.0 & 2.5 & 12.0 & 2.6 \\
\hline $1992-93$ & 5.4 & 4.3 & 5.6 & 5.9 & 4.6 \\
\hline 1993-94 & 3.9 & 5.6 & 7.1 & 13.4 & 3.5 \\
\hline 1994-95 & 5.3 & 10.3 & 10.4 & 5.6 & 3.2 \\
\hline Average & 3.6 & 5.3 & 6.1 & 8.9 & 3.6 \\
\hline $1995-96$ & -0.3 & 12.3 & 13.3 & 8.2 & 7.9 \\
\hline 1996-97 & 8.8 & 7.7 & 7.8 & 7.0 & 6.3 \\
\hline 1997-98 & -1.5 & 3.8 & 7.8 & 11.6 & 11.7 \\
\hline 1998-99 & 5.9 & 3.8 & 7.7 & 7.4 & 10.4 \\
\hline 1999-00 & 0.6 & 4.9 & 8.5 & 10.6 & 12.2 \\
\hline Average & 2.6 & 6.5 & 9.0 & 8.9 & 9.7 \\
\hline 2000-01 & 0.2 & 6.7 & 7.1 & 4.1 & 4.7 \\
\hline 2001-02 & 5.8 & 2.8 & 9.2 & 7.3 & 3.9 \\
\hline 2002-03 & -5.6 & 6.8 & 9.1 & 8.0 & 3.8 \\
\hline 2003-04 & 9.6 & 7.9 & 12.0 & 4.5 & 5.4 \\
\hline 2004-05 & 1.2 & 8.9 & 10.6 & 9.2 & 9.2 \\
\hline Average & 2.1 & 6.6 & 9.6 & 6.6 & 5.4 \\
\hline
\end{tabular}

Source: Economic Survey 2005-2006. Ministry of Finance, Table 1.6. From 2001-02 new series at 19992000 prices. Before 2001-02 at 1993-94 prices. Averages: authors' own calculations.

As illustrated in the previous section, despite its limitations, growth accounting can provide some insight into the approximate causes of growth. In addition, other techniques such as growth regressions are often employed to analyse the impacts of the immediate causes, such as quantity and quality of labor and capital as well as the 'fundamental determinants' of growth. It is, however, important to note that both methods have been heavily criticised in the literature. ${ }^{15}$

Without going into the technical details of these debates, let us conclude this section by taking a look at these 'fundamental determinants of growth' for the Indian case. Most scholars seem to agree on the fundamental determinants of growth: physical and human capital investments, quality of institutions or governance, and investment climate. While the gross domestic capital formation ratio (33\% - see Table 1) is rather high, India's low literacy rate $(61 \%)$ could potentially become a constraint on India's long term growth prospects. And what about India's institutions and investment climate?

\footnotetext{
${ }^{15}$ See for instance Durlauf et al. (2004). See also Bosworth and Collins (2003) for additional references on these critiques.
} 
In order to answer this question, we took a look at the World Bank's 'ease of business' indicator, which can be viewed as a measure of investment climate. This indicator ranks economies in terms of their 'ease of business', from 1 to 175 , with 1 referring to the best. This index averages the country's percentile rankings on 10 categories, giving equal weight to each category. Each category in its turn averages the country's percentile rankings on different sub-categories. ${ }^{16}$ According to the latest indicators, India ranks 134 out of 175 and is situated around the average rank of low-income countries, above the majority of the Sub-Saharan African countries and below most South and South-East Asian and Latin American developing countries. From Table 7, one can see that India ranks relatively high in the 'getting credit' and 'protecting investors' spheres, but particularly low in the areas of 'dealing with licenses', 'paying taxes' and 'enforcing contracts'. In these areas, as well as in the areas of 'employing workers' and 'closing a business', most analysts would agree that further reforms are needed.

Table 7

Cross Country Comparison of Ease of Business Indicators (2006)

\begin{tabular}{|c|c|c|c|c|c|}
\hline \multirow[b]{2}{*}{ Category } & \multicolumn{4}{|c|}{ Average Rank } & \multirow[b]{2}{*}{ India } \\
\hline & $\begin{array}{l}\text { Low Income } \\
\text { Countries }\end{array}$ & $\begin{array}{l}\text { Lower- } \\
\text { Middle } \\
\text { Income } \\
\text { countries }\end{array}$ & $\begin{array}{c}\text { Upper- } \\
\text { Middle } \\
\text { income } \\
\text { Countries }\end{array}$ & $\begin{array}{c}\text { High } \\
\text { Income } \\
\text { Countries }\end{array}$ & \\
\hline Starting a Business & 116 & 98 & 71 & 45 & 88 \\
\hline Dealing with Licenses & 115 & 94 & 75 & 49 & 155 \\
\hline Employing Workers & 107 & 85 & 81 & 70 & 112 \\
\hline Registering Property & 113 & 96 & 76 & 48 & 110 \\
\hline Getting Credit & 121 & 80 & 69 & 32 & 65 \\
\hline Protecting Investors & 94 & 96 & 67 & 50 & 33 \\
\hline Paying Taxes & 105 & 101 & 75 & 52 & 158 \\
\hline Trading Across Borders ${ }^{1}$ & 130 & 96 & 71 & 30 & 139 \\
\hline Enforcing Contracts & 111 & 95 & 91 & 39 & 173 \\
\hline Closing a Business & 117 & 94 & 87 & 26 & 133 \\
\hline Overall rank & 133 & 97 & 67 & 27 & 134 \\
\hline GNI per capita $(\$)$ & 436 & 2037 & 6431 & 30763 & 720 \\
\hline
\end{tabular}

Source: Doing Business 2007. World Bank. Notes (1) the 'trading across borders' measure does not include tariffs or trade taxes.

The 'dealing with licenses' indicator is of particular interest in the Indian case as it is often viewed as a residue of the license raj that characterised India before the 1980s (Aghion et al., 2006). ${ }^{17}$ According the World Bank figures, India has not improved much

\footnotetext{
${ }^{16}$ Note that the World Bank figures consider only the official costs and times involved for a standardized firm, assuming perfect knowledge about the procedures, these measures most likely underestimate the real costs involved. In addition, the rankings do not take into account that the opportunity cost of time differs across countries; 1 day waiting in India is not the same as one day waiting in the US. On a similar note, as the GNI is much higher in the High Income countries, a low cost as a \% of the GNI is in a way 'easier' to achieve; also as this cost is not calculated as a \% of the PPP GNI, the actual perceived costs in developing countries might be lower than is suggested by the World Bank figures. It is unclear how these data issues affect the relative ranking of the countries.

${ }^{17}$ Some, first-hand descriptive accounts of India's burgeoning bureaucracy occur in Basu (2007b).
} 
over the last two years. In India one needs on average 270 days to complete all the procedures required to build a standardised warehouse in the construction industry, this is considerably higher than the average of the Low Income countries (231 days). India's cost measure of this indicator gives a slightly more optimistic picture. Obtaining the necessary licenses to build the warehouse costs $606 \%$ (of the GNI per capita), which is in between the averages of the Low Income countries (996\%) and the Lower-Middle Income countries $(558 \%)$.

Many scholars have argued that India's performance is surprisingly low when compared to the quality of its institutions. ${ }^{18}$ Rodrik and Subramanian (2004b), for instance, using geography, openness, economic and political institutes as fundamental determinants of growth, conclude that 'India's level of income was about a quarter of what it should be given the strength of its economic institutions. On the other hand, if political institutions are the true long-run determinant of income, India's income is about 15 percent of what it should be. India has thus been a significant under-achiever in the sense that it has not exploited the potential created by having done the really hard work of building institutions.' In their analysis they used settler mortality, fraction of the population speaking one of the major languages of Western Europe, or fraction of the population speaking English as an instrument for institutions, as described in Rodrik, Subramanian and Trebbi (2002).

\section{GROWTH, THE POLITICAL ECONOMY OF}

The previous section gave an overview of India's growth performance over the last 50 years and briefly outlined the elements of the current debate in the literature on India's growth performance. This section tells the story behind the figures.

The first real big growth year for India, 1975-76, was also one that stood out politically as one of the most salient, if not notorious, year for the nation. That year the country's GDP grew by $9 \%$, a figure that has been surpassed only twice since then ${ }^{19}$. That was also the year in which the then Prime Minister, Indira Gandhi, declared an Emergency and established dictatorial control over the nation. This would last for two years. In 1977 Indira Gandhi called an election. There is no way of knowing if this was prompted by an exaggerated sense of popularity on her part or because of a genuine fatigue she felt with totalitarian control. But the fact of the matter is that she was routed at the polls, and she would return to power (re-elected) only in 1980.

Some of the growth spurt of the early Emergency period would get undone in 1979-80, the worst performing year in the history of independent India, but 1974 to 1979, as already noted, was nevertheless to be the cross-over plan period when average annual growth rate breached the $5 \%$ mark.

\footnotetext{
${ }^{18}$ See for instance Srinivasan (2005).

${ }^{19}$ One of these is the current year, 2006-07, the growth rate for which is estimated to be $9.2 \%$.
} 
Thanks to the totalitarian embarrassment of 1975, most Indian commentators are loathe to identify that year as a break in the trend for the economy. ${ }^{20}$ Yet there is no denying that it was, even though the sustainability of that growth impulse may be questionable. The next improvement would come in the early 1980s, when not only did the growth rate pick up further but, as pointed out above, the country broke ranks with other nations. The next change, which in our opinion was the big and sustainable change and is often thought of as a structural break, occurred in 1991, when, pushed by a macroeconomic crisis, itself caused by the first Gulf war and drying up of foreign reserves, Indian undertook the most major reforms since independence ${ }^{21}$.

If these are the three landmark years - and clearly this matches reasonably well with the statistical analysis, what were the factors that led to them? There were important policy changes true, but what does not always get adequate credit in the case of India are the two closely-related variables that are identified in standard growth theory as among the most significant factors-the savings and investment rates ${ }^{22}$. These rates, which were traditionally very low in India, around 15\% till the late sixties, began climbing all through the seventies and crossed the $20 \%$ mark in 1978-79. This must have contributed to the greater growth momentum of the mid-seventies, and in fact the persistent growth that we have seen since the early eighties. The extra spike in the year 1975-76 did probably owe something to the Emergency. Trains do run on time in the first flush of dictatorship and there is anecdotal evidence that this and other work-related efficiencies were adopted in that year. But that first flush soon vanished and thanks to severe shortages in infrastructural resources, the economy too slowed down severely by the end of the seventies.

A natural question that arises is: What caused the rising savings rate? Unfortunately, this question has not received sufficient attention and no clear answer to this is available. It seems to us however that it had something to do with the nationalization of banks that Indira Gandhi announced in $1969^{23}$. After the nationalization, the banks were forced to open branches in remote, 'unprofitable' areas. This, coupled with the impetus that came with the formation of the state-owned Unit Trust of India in 1964, may have prompted greater savings by making savings easier and safe (Shetty, 2007). Table 8 shows that there was indeed a phenomenal increase in the number of bank branches in India, following the nationalization; so some prima facie evidence for this hypothesis is indeed there.

\footnotetext{
${ }^{20}$ To the extent that the value of democracy is not purely instrumental but as an end in itself, over 1975-77 must overall go down as dark years in India's history. For a discussion of India's democracy and development, see Sen (2004).

${ }^{21}$ Why the Indian reforms came so late and only when the nation was pushed against the wall is itself an interesting question. It may have something to do with India's democracy which is quite unique. All the currently-developed democratic nations adopted democracy with universal suffrage, after the process on industrialization was firmly in place. India adopted universal suffrage at independence, at a level of poverty with few parallels; and so it has had to contend with the opinion of the poor in ways that are quite alien to the industrialized nations of today (Varshney, 2007). This may also have something to do with the tenacity of India's labor laws discussed below.

${ }^{22}$ See Majumdar (1997) for discussion of growth theory in the context of the Indian economy.

${ }^{23}$ The Supreme Court of India initially declared the nationalization to be not valid. But Indira Gandhi amended the law and passed the nationalization decision by an ordinance.
} 
The opening of branches and making savings and borrowing outlets available to poorer citizens was an explicit objective of the nationalization ${ }^{24}$. And while its impact on savings awaits formal investigation, there are other kinds of related studies that do suggest a large impact of the nationalization of banks on ordinary citizens ${ }^{25}$. Burgess and Pande (2005), for instance, test whether this large state-led bank branch expansion program was associated with poverty reduction in India, given that an integral element of this program was branch expansion into rural unbanked locations. The paper's main finding is that branch expansion into rural unbanked locations in India significantly reduced rural poverty. It seems natural to expect that such a large banking initiative did cause a boost in savings, especially since it coincided with the rise in India's savings rate.

Another reason for the increasing savings rate could be the increasing real interest rate (Table 9). These are positive and show an increasing trend since 1974. Yet, most detailed studies of savings find a rather weak connection between interest rates and savings (Rao, 2007; Shome, 2007), suggesting that consumers are more interested in long-run prospects and the facilities for saving than the immediate lure of interest. As Shome (p.464) remarks, "But it is clearly the growth in financial intermediation that stands out most as the main driver of savings."

Table 8

Number of Bank Branches in India (Scheduled and Non-Scheduled Commercial Banks)

\begin{tabular}{lc}
\hline Year & Number \\
\hline 1941 & $2074^{(1)}$ \\
1951 & 4119 \\
1961 & 5113 \\
1969 & 9051 \\
1971 & 12985 \\
1976 & 23656 \\
1981 & 38047 \\
1986 & 53397 \\
1991 & 62740 \\
1996 & 64937 \\
2001 & 67856 \\
2005 & 70324 \\
\hline
\end{tabular}

Source: Statistical Tables Related to Banks in India, 2005-2006 and previous issues. Reserve Bank of India, (1) India and Burma (now Myanmar). Note the figures from 1991 onwards are from $31 \mathrm{March}$, while the ones before that date are from 31 December

\footnotetext{
24 "The banking system touches the lives of millions and has to be inspired by larger social purpose and has to subserve national priorities and objectives such as rapid growth of agriculture, small industries and exports, raising of employment levels, encouragement of new entrepreneurs and development of backward areas. For this purpose it is necessary for the government to take direct responsibility for the extension and diversification of banking services and for the working of a substantial part of the banking system." (Bank Company Acquisition Act, 1969).

${ }^{25}$ Economic analysis of banking reform is a relatively scarce discipline in India. For recent work, see Banerjee, Duflo and Cole (2003, 2004).
} 
Let us look at some statistics on the growth of savings in India. Bosworth et al. (2007) report that not only have national savings risen considerably since the 1980's, but that in particular household savings have risen from 10\% to 25\% of GDP during the last 30 years. Half of this is in the form of financial savings, which can be channeled back into other sectors as investment. Public sector saving, however, has not performed as well. From a high of around 4\% in the 1970's, it became negative in the late 1990's, recovering only recently. These trends are noted in Figure 3. Note that savings are reported here as percentage of GNP at factor costs. It is also important to note that savings have risen particularly in the post-liberalization years. Whether there is a link between higher savings and post-liberalization policies needs to be further researched.

Table 9

Nominal and Real Lending Rates, 1970-2004

\begin{tabular}{lrrrrrrr}
\hline Year & $1970-74$ & $1975-79$ & $1980-84$ & $1985-89$ & $1990-94$ & $1995-99$ & $2000-04$ \\
\hline Nominal lending rate & 9 & 10.4 & 13.3 & 13.9 & 16.7 & 15.2 & 11.4 \\
Inflation rate & 15.3 & 4.7 & 9.3 & 6.7 & 11 & 5.3 & 5.2 \\
Real interest rate & -4.9 & 5.9 & 3.9 & 6.8 & 5.2 & 9.4 & 5.9 \\
\hline
\end{tabular}

Source: Bosworth et al. (2007), Table 12.

Note: The nominal lending rate is an average of the rates for four major lending institutions. The inflation rate is measured by the annual rate of change in the wholesale price index for all commodities.

To conclude, the rise in India's savings rate deserves more detailed investigation than has occurred thus far. Given that India is currently in the midst of another sharp rise in savings (the first since the late seventies), this is a subject of contemporary relevance.

Figure 3

Domestic Savings per Sector

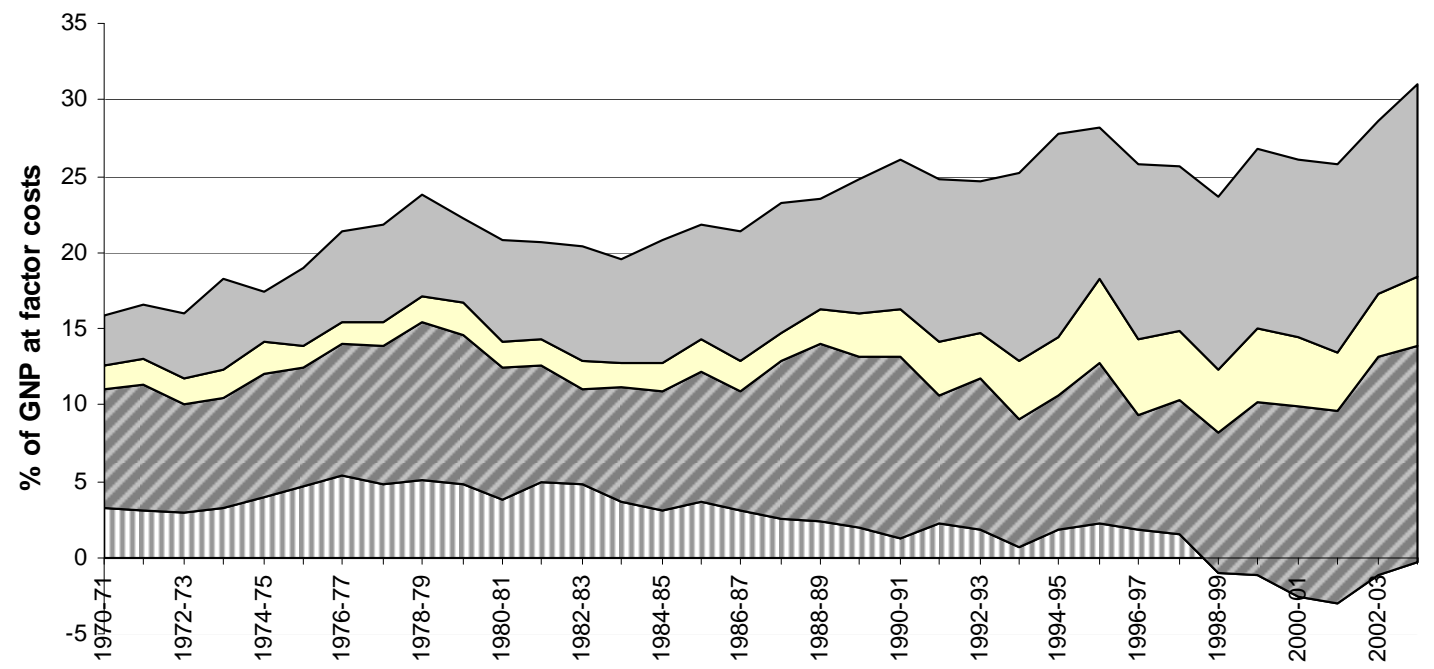

$\square$ Public Sector Savings $\square$ Household Physical Savings $\square$ Corporate Sector Savings $\square$ Household Financial Savings

Source: Handbook of Statistics on the Indian Economy. 2006. Reserve Bank of India (Table 10 and Table 1). Notes: old series (base: 1993-94) used for calculation. 
The second acceleration - in the early 1980s probably owes something to altered policies and of course it came with a background of higher investment and savings rates. The change in policy regime makes for interesting political sleuthing. It seems to have much to do with Indira Gandhi's altered perceptions. The reading of descriptive accounts of her regime (for instance, Dhar, 2000; Frank 2002) suggests that unlike her father, Nehru, India's first Prime Minister, Indira Gandhi never had strong convictions about economic policy. Her early commitment to 'socialism' was arguably prompted by an instinctive following of her father's convictions and policies, without any deep convictions of her own. She nationalized banks, established control over grain trade as homage to her father without a coherent plan for the whole economy as such.

By the mid-seventies she was under the influence of another man-her younger son, Sanjay Gandhi. Sanjay was not committed to any well thought out ideology but was wary of Congress socialism. What was notable about him was his vaulting ambition and, along with his entrepreneurial friends, he pushed India towards crony capitalism. There has been much that has been written about his disproportionate influence on his mother. In an interview that he gave in July 1976, he openly criticized the Communist Party of India (an ally of Indira Gandhi) and disparaged earlier policies of the Congress. Mrs. Gandhi was upset by the interview and summoned P. N. Dhar, who headed her secretariat, and told him, "Sanjay has done something terrible and I am upset." (Dhar, 2000, p. 325) The conversation that followed where she asked Dhar to do the damage control suggested to him that she was "afraid of" his "displeasure." As time progressed and she felt more and more isolated from her own party and other politicians, she turned increasingly to her son, who had visions, without wisdom, of an entrepreneurial revolution, mainly under the ownership of him and his friends ${ }^{26}$.

By the early eighties India started out on a path of openly capitalist development. Even though this was done with no systematic vision and with favours doled out to those close to the government, it boosted growth, as the statistical analysis above shows. The economy had for so long been shackled by bureaucratic rules and red tape that the release from these, however small, caused a rise in growth. Moreover, by now India had higher investment and savings rates to support this.

By the late eighties, even though the country was growing fast, it was beginning to borrow heavily from its future, which makes us believe that the growth impulse of the eighties would not have been sustainable without sharp changes in policy. The fiscal deficit was growing, international debt was reaching record levels and the debt-service ratio had reached become untenable. The meltdown happened in the 1990-91. The first Gulf War was the proximate cause but the bubble was anyway ready to burst. Huge amounts have been written on this crisis ${ }^{27}$ and we will not go into that here. But the crisis became an impetus for economic reform. By 1991 government had changed hands. Narasimha Rao was Prime Minister and Manmohan Singh was his Finance Minister. Under their stewardship a reform started, more far-reaching than any since the early days of Nehru's government. Industrial licensing was discarded and the astronomical import

\footnotetext{
${ }^{26}$ Sanjay Gandhi died when a plane that he was flying crashed on 23 June 1980.

${ }^{27}$ See, for instance, Desai (1994), Srinivasan (2000), Ahluwalia (2002), Bardhan (2004), Basu (2004) and Chidambaram (2007).
} 
tariff rates were set on a sharp downward course. The first two years of the reform were a difficult time for the economy. But in terms of overall growth rate and performance in the international sector the Indian economy has not looked back since then. From 1994 to 1997 the economy grew at a rate of above $7 \%$ for three successive years, slowing down a little after that as a result of the general East Asian crisis; but over the last few years the growth rate has picked up again. It has not dropped below 7.5\% per annum since 2003 and has thrice crossed the $8 \%$ mark. What has been powering this new growth and was the big success of the reforms was the international sector. India's foreign exchange balance started rising from a precarious low in 1991, when the country was on the verge of default to a very comfortable level. As Table 10 shows the reserves had fluctuated but on balance remained low for several decades, up to 1990. Since then, with the reforms marking an excellent dummy variable, it has grown sharply. Currently, India is among the world's five largest foreign reserve holders.

Table 10

Foreign Exchange Reserves in India, Selected Years

\begin{tabular}{ccccc}
\hline Year & $\begin{array}{c}\text { Foreign Exchange } \\
\text { Reserves } \\
\text { (\$ millions) }\end{array}$ & $\begin{array}{c}\text { Aggregate Export } \\
\text { of Goods and Services } \\
\text { (\$ millions) }\end{array}$ & $\begin{array}{c}\text { Short-Term Debt, } \\
\text { (as \% of Foreign } \\
\text { Reserves) }\end{array}$ & Debt-Service Ratio \\
\hline 1977 & 5,824 & & & \\
1990 & 5,834 & 18,477 & 129 & 35 \\
1994 & 25,186 & 26,855 & 14 & 18 \\
1998 & 32,490 & 34,298 & 16 & 14 \\
2002 & 75,428 & 52,512 & 10 & 6.2 \\
2005 & 130,000 & 68,000 & 5.7 & 5 \\
\hline
\end{tabular}

Source: Economic Survey (various), Ministry of Finance, Government of India; and Press Releases of the Ministry of Commerce.

Even exports have risen, especially when one includes software and informationtechnology-related invisibles within exports. ${ }^{28}$ According to World Bank figures (see Figure 4) exports, as percentage of GDP, crossed 10\% for the first time in 1992 and are currently over $19 \%$. With the rise in foreign exchange balance and the confidence of success in the software and pharmaceuticals sector, Indian corporations have gone on a spree of buying international companies, an activity unheard of ten years ago. It is this international presence and visibility that has given India the somewhat disproportionate global media attention. But that in itself is an advantage since it has boosted confidence in the country, pouring money into the Indian bourses, and become partly self-fulfilling.

While the economic reforms of 1991-93 lie behind the international success of the country, there is more to the story, especially over the last four or five years and this, once again, intertwines with politics, this time global politics.

There are two factors worth drawing attention to ${ }^{29}$. First, there was one unintended positive spillover of the last US presidential election. During the election campaign,

\footnotetext{
${ }^{28}$ For an analysis of India's success in software and information technology, see Kapur (2002) and Murthy (2004).

${ }^{29}$ A more detailed discussion of this occurs in Basu (2006b).
} 
outsourcing back office work to developing countries came under heavy criticism, with some television shows, such as that of Lou Dobbs, attacking U.S. entrepreneurs for profiteering by outsourcing work. This had a huge advertisement effect for the advantages of outsourcing. Most poor countries would not be able to afford such advertising on American television; they suddenly got this for free. Small U.S. entrepreneurs, who were unaware of this profit opportunity, learned about it and began outsourcing and India's already large outsourcing business received another boost.

Figure 4 Export and Imports as a Percentage of GDP in India, 1965 -2004

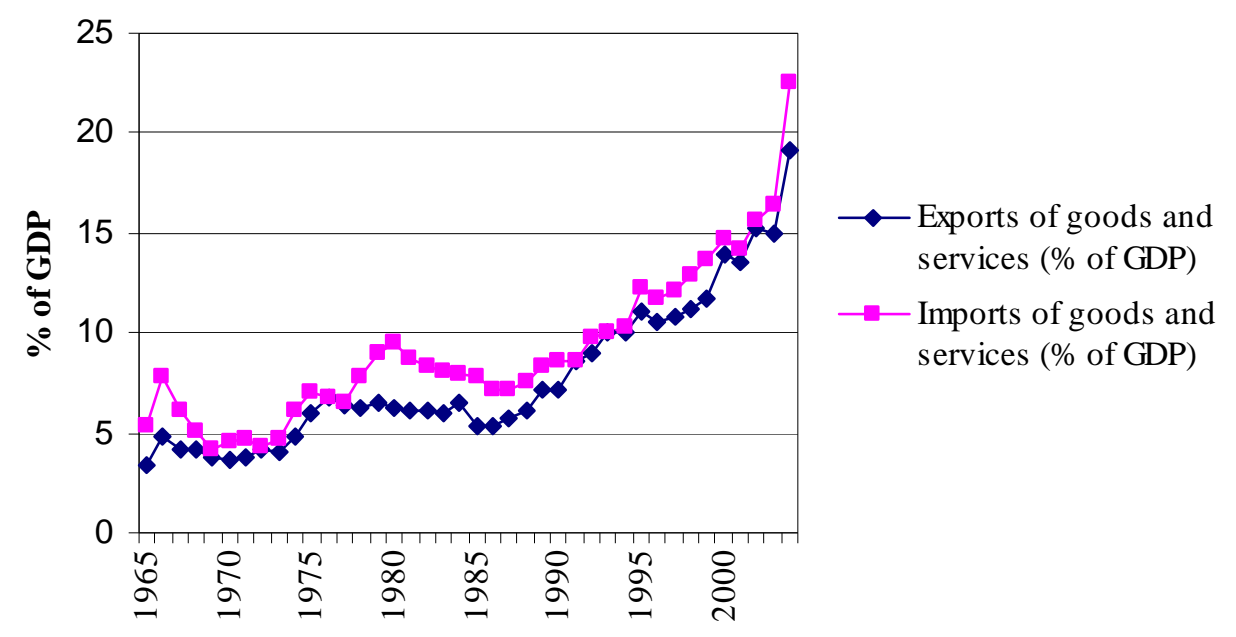

Source: World Development Indicators 2006, World Bank

Second, having an alignment of interest with the world's most powerful nation, the U.S., can have large benefits for an economy. We have seen this happen in the case of South Korea since the fifties. Shifts in global geo-political balance of power have suddenly brought India into the ambit of U.S. interest. As long as America's main foreign policy concern was Communism and the USSR, it had little use for India. But now with terrorism being the main global concern of the US, it has shared interests with India, which are deeper than the tactical ties currently with Pakistan. Also, with the rise of China, the U.S. has apprehensions of a new unipolar world with China at the centre or, what is only marginally better, a direct face off with China in a bipolar world. In the event of a showdown between these two countries, the risks for the U.S. are huge. If China cuts off or monitors trade flows through the Strait of Malacca, the biggest sea route for trade in today's world, this can have very large consequences for the American economy. China also has a disproportionate leverage on the value of the dollar, thanks to its large foreign exchange holdings. India is viewed by the United States as a 
counterpoise for all these risks, and India's economy has benefited from this emerging geo-political advantage. ${ }^{30}$

But we want to turn now from these macroeconomic aggregates and broad global issues to the microeconomic foundations of what is happening in India. The advantages of global politics can easily be dissipated, as we saw in the case of the former Soviet Union, if a country's economic 'nuts and bolts' do not function well. There is now increasing data on the microeconomic institutions that permit businesses to thrive and grow and play a crucial role in an economy's long-run trajectory. The next section examines some of these issues.

\section{MICROECONOMIC FOUNDATIONS}

India's initial focus on the international sector has paid off handsomely. But to sustain this growth microeconomic issues need greater attention-better distribution of income, improved labor market functioning, the control of corruption, and more efficient institutions for business and enterprise. These are often referred to as second generation reforms. There is no effort here to cover all these microfoundational issues, each of which can be the subject of a full-length paper, but to comment on one, namely, labor-market regulation, on which we have insights to offer, which are not common wisdom.

While the Indian economy is booming, there is evidence that workers are not partaking in the boom adequately. Employment is not growing as fast as working age population, nor are wages rising as rapidly as per capita income. There are many reasons for this-some to do with forces of globalization that are beyond the Indian government's policy reach. But much of it has to do with the 'culture' that pervades India's labour markets, which in turn is a consequence of the complicated and ill-conceived laws that govern the labour market.

In India there are 45 laws at the national level and close to four times that at the level of state governments that monitor the functioning of labour markets. This complexity gets reflected in the World Bank's Ease of Business Indicators, where India ranks 112 out of 175 countries in the category 'employing workers' in 2006 (with 1 referring to the best). Even though recent changes in the regulation of several Indian states have resulted in a lower 'difficulty of hiring index', 'rigidity of hours index', 'rigidity of employment index' and 'firing costs', India still scores high on the 'difficulty of firing' index (70/100), which is considerably higher than the average of the Low Income countries (44/100).

Some of these labor laws date back to the nineteenth century. They were meant to control conflict and keep the labour market efficient. Unfortunately, the experience has been to the contrary. According to recent World Bank estimates, in 2004, there were 482 cases of major work stoppages, resulting in 15 million human days of work loss (World Bank, 2006). Between 1995 and 2001 around $9 \%$ of factory workers were involved in these

\footnotetext{
${ }^{30}$ Interestingly, Indo-Chinese relations have also improved steadily since Rajiv Gandhi's visit to China in 1989; and trade between India and China has grown exponentially over the last four years (see Ramesh 2005).
} 
stoppages. The figure for China is close to zero. On the other hand, the wages of Chinese workers are rising much faster than those of India's. These facts, we would argue, are not unrelated.

Most of India's labour laws were crafted with scant respect for 'market response.' If X seemed bad, the presumption was that you had to simply enact a law banning X. But the fact that each law leads entrepreneurs and labourers to respond strategically, often in complicated ways, was paid no heed. In a poor country no one with any sensitivity wants workers to lose their jobs. So what does one do? The instinct is to make it difficult for firms to layoff workers. That is exactly what India's Industrial Disputes Act, 1947, did, especially through the amendments of 1976 and 1982, for firms in the formal sector and employing more than 100 workers.

But in today's globalised world, with volatile and shifting demand, firms have responded to this by keeping their labour force as small as possible. It is little wonder that in a country as large as India less than 10 million workers are employed in the formal private sector. Some commentators have argued that India's labour laws could not have had much of a consequence since most of them apply to only the formal sector. What they fail to realize is that one reason the formal sector has remained miniscule is because of these laws and also the culture that these laws have spawned (Basu, 2006a).

Several recent studies have analyzed the impacts of labor regulations on firm productivity, patterns of specialization and technological progress. According to Besley and Burgess (2004), increasing pro-worker regulation has a negative impact on investment and productivity in the registered manufacturing sectors. What is also interesting about their findings is the lack of evidence that such policies improve labor interests. Aghion and Burgess (2003) confirm these results and in addition show that the negative impact of having stricter labor regulations on productivity has increased in the period post-liberalization. Kochar et al (2006), based on their analysis of the patterns of specialization of Indian firms, suggest that not only is the level of productivity of existing firms affected by stringent regulations, but new firms are either kept from entering as a result.

What is needed in India is not a law that allows employers to fire workers at will but one that allows for different kinds of contracts. Some workers may sign a contract for a high wage but one that requires them to quit at short notice; others may seek the opposite. This would allow firms to employ different kinds of labour depending on the volatility of the market they operated in.

Much of the debate on labour laws has been misconstrued. What is needed is not change in labour laws and policy to elicit sacrifice from organized labour, as some economists have suggested. Indian workers, whether they be in the organized sector or the unorganized sector, are too poor for that. The need is for changes in order to create greater private-sector demand for labour, which will boost wages and employment. We believe that India's poorly construed labor laws have been so persistent because of an intellectual failure, to wit, the inability to grasp that it may be in the worker's own interest (in some contexts) to have the right to waive some rights that have been granted to the worker. 
It should be clarified that we are not making the case to give all workers the right to give up their right to call strikes or the right to continue to work, but simply arguing that there are contexts where it is worthwhile giving them the meta right to give up some right. One has to weigh lots of pros and cons before making a general recommendation. We feel that the right to strike has other advantages so that, barring some very special cases, workers should always have this right. On the other hand, we believe that in India workers should be given the right to sign contracts with different kinds of firing or retrenchment rules and that, doing so, is likely to cause such a rise in aggregate demand for labor that all workers will be better off. While much of the current debate in India on labor laws is conducted as though worker interests are pitted against business interests, in reality, it is between thinking clearly and not thinking clearly.

It should also be added that flexibility in hiring and firing is not the only problem. India's complex web of legislation leads to a system of dispute resolution that is incredibly slow. Data from the Ministry of Labour reveal that in the year 2000 there were 533,038 disputes pending in India's labour courts; and of these 28,864 had been pending for over 10 years. If India is to be a vibrant global economy, this has to change.

In brief, the need is to move to a system that (1) makes room for more flexible contracts in the labour market, (2) has a minimal welfare net for workers who are out of work, and (3) resolves labour market disputes more quickly.

\section{CONCLUSION}

To conclude, if India wants to sustain and raise even higher its current growth the main bottlenecks in the Indian economy will need to be addressed. These are infrastructure (roads, expensive freight rates, power supply, ports and airports), labor and bankruptcy regulations, and the high level of corruption in the government bureaucracy. In addition, the current erratic and low growth pattern of the agricultural sector, and the rising inequality, between states, between rural-urban areas, and within urban and rural areas mainly since the 1990s, are a concern.

Of these numerous factors, we had occasion to address only a few in this paper. Each of these deserves inquiry, research and policy initiative, but in concluding we will just remark briefly on one of them--the subject of inequality.

Comparing the ratio of the income share of the richest $10 \%$ over the poorest $10 \%$ in India with other countries, one may be tempted to conclude that inequality in India is not abnormally high. According to the World Bank's World Development Indicators 2006, this ratio is 7.2 in India (in 2000), compared to 18.36 in China (in 2001), 48 in Guatemala (in 2002) and 15.9 in the US (in 2000). As such, India's current inequality seems to be low and comparable to some of the Western European nations. But one has to remember that a poor country will have a natural tendency for greater equality, since people cannot survive below a certain level of income. To take an extreme case, a country that has a per capita income equal to the subsistence income will, by definition, have no income 
inequality. Hence, despite the seemingly encouraging inequality ratio mentioned above, inequality-especially when it results in higher poverty--is a serious problem for India. This can lead to political tensions and can destabilise the otherwise optimistic growth scenario. But, even if it does not dampen the country's growth prospects, it seems to us that greater equity and the reduction of poverty are valuable ends in themselves. Indeed it is arguable that growth is valuable precisely because it enables a country to banish poverty and achieve greater equality. India's trajectory over the last fifteen years has been remarkable, but there will be reason to truly celebrate this when the overall gains filter down to the poorest and the most deprived sections of India's vast population. 


\section{REFERENCES}

Acharya, Shankar (2004), 'India's Growth Prospects Revisited', Economic and Political Weekly, October 9, 4537-4542.

Aghion, Philippe and Burgess, Robin (2003), 'Liberalization and Industrial Performance: Evidence from India and the UK', conference paper presented at the conference the Future of Globalization at Yale University in 2003.

Aghion, Philippe, Burgess, Robin, Redding, Stephen and Zilibotti, Fabrizio (2006), 'The Unequal Effects of Liberalization: Evidence from Dismantling the License Raj in India', Centre for Economic Performance, LSE, CEP Discussion Papers.

Agarwal, Pradeep (2003), 'Economic Impact of Foreign Direct Investment in South Asia,'in Mattoo, Aaditya and Stern, Robert M. (eds.), India and the WTO, World Bank and Oxford University Press, 117-139.

Ahluwalia, I.J., 1995, “India: Industrial Development Review,” The Economist Intelligence Unit and UNIDO.

Ahluwalia, Montek S. (2002), 'Economic Reforms in India since 1991: Has Gradualism Worked?', Journal of Economic Perspectives, 16(3), 67-88.

Babu, Suresh M. (2005), 'India's Recent Economic Growth, Some Limits and Limitations', Economic and Political Weekly, July 23, 3249-3252 .

Balakrishnan, P. and Parameswaran M. (2006). 'Identifying Growth Regimes in India', presented at the South and South East Asian Econometric Society, December 19, Chennai, India.

Banerjee, Abhijit V. (2006), 'The Paradox of Indian Growth: A Comment on Kochar et al', Journal of Monetary Economics, 53(5), 1021-1026.

Banerjee, Abhijit V., Cole, Shawn and Duflo, Esther (2003), 'Bank Financing in India', MIT Department of Economics Working Paper.

Banerjee, Abhijit V., Cole, Shawn and Duflo, Esther (2004), 'Banking Reform in India', MIT Department of Economics Working Paper.

Bardhan, Pranab (2004), 'Disjunctures in the India Reform Process: Some Reflections', in Kaushik Basu (ed.) India's Emerging Economy: Performance and Prospects in the 1990s and Beyond, Cambridge MA, MIT Press and New Delhi: Oxford University Press.

Basu, Kaushik (2004), 'The Indian Economy: Up to 1991 and Since' in Kaushik Basu (ed.), India's Emerging Economy: Performance and Prospects in the 1990s and Beyond, Cambridge, MA, MIT Press and New Delhi, Oxford University Press. 
Basu, Kaushik (2006a), 'Labor Laws and Labor Welfare in the Context of the Indian Experience,' in Alain de Janvry and Ravi Kanbur (eds.), Poverty, Inequality and Development, New York, Springer.

Basu, Kaushik (2006b), 'India Globalizing,' in David A. Kelly, Ramkishen S. Rajan and Gillian H.L. Goh (eds.) Managing Globalization: Lessons from China and India, Singapore, World Scientific Publishing.

Basu, Kaushik (ed.) (2007a), Oxford Companion to Economics in India, New Delhi, Oxford University Press.

Basu, Kaushik (2007b), The Retreat of Democracy and other Itinerant Essays and Economic Globalization and India, New Delhi: Permanent Black, Forthcoming

Besley, Tim and Burgess, Robin (2004), 'Can Labor Regulation Hinder Economic Performance? Evidence from India', Quarterly Journal of Economics, 119 (1), 91-134.

Bhagwati, Jagdish N. (2004), 'International Flows of Humanity,' in In Defense of Globalization, Oxford University Press, Chapter 14, 208-218.

Bosworth, Barry P. and Collins, Susan M. (2003), 'The Empirics of Growth: An Update', Working Paper Brookings Institution, Washington.

Bosworth, Barry P., Collins, Susan M. and Arvind Virmani (2007), 'Sources of Growth in the Indian Economy,' Forthcoming in India Policy Forum.

Burgess, Robin and Pande, Rohini (2003), 'Do Rural Banks Matter? Evidence from the Indian Social Banking Experiment', BREAD Working Paper No. 037.

Burgess, Robin and Pande, Rohini (2005), 'Do Rural Banks Matter? Evidence from the Indian Social Banking Experiment', American Economic Review, 95(3), 780-795.

Chidambaram, P. (2007), 'Fiscal Policy Reforms since 1991,' in Basu (2007a).

Dasgupta, Sukti and Singh, Ajit (2005), 'Will Services be the New Engines of Indian Economic Growth?', Development and Change 36(6), 1035-1057.

De Long, Bradford J. (2003), 'India since Independence: An Analytic Growth Narrative' in Dani Rodrik (ed.), In Search of Prosperity: Analytic Narratives on Economic Growth, New Jersey, Princeton University Press.

Deaton, Angus and Drèze, Jean (2002), 'Poverty and Inequality in India: A Reexamination', Economic and Political Weekly, September 7, 729-48.

Desai, Ashok V. (1994), My Economic Affair, New Delhi, Willey Eastern Ltd.

Dhar, P.N. (2000), Indira Gandhi, the 'Emergency' and Indian Democracy, New Delhi, Oxford University Press.

Dholokia, Bakul H. 2002. 'Sources of India's Accelerated Growth and the Vision of the Indian Economy in 2020,' The Indian Economic Journal, 29(4), 27-46. 
Dreze, Jean and Sen, Amartya (2002), India, Economic Development and Social Opportunity, Oxford University Press.

Durlauf, Steven, Johnson, Paul A. and Temple, Jonathan R.W. (2004), 'Growth Econometrics', University of Wisconsin-Madison Department of Economics Research Paper.

Dyson, Tim, Cassen, Robert and Visaria, Leela (2004), Twenty-First Century India, Population, Economy, Human Development and the Environment, Oxford University Press.

Forbes, Naushad (2002), 'Doing Business in India: What has liberalization changed?', in Anne O. Krueger (ed.), Economic Policy Reforms and the Indian Economy, Chicago and London, University of Chicago Press, 129-67.

Frank, Katherine (2002), Indira: The Life and Times of Indira Nehru Gandhi, London: Harper Collins.

Goldar, Bishwanath and Mitra, Arup (2002), 'Total Factor Productivity Growth in Indian Industry: a Review of Studies," in B.S. Minhas (ed.) National Income Accounts and Data Systems. New Delhi: Oxford University Press: 218-37.

Himanshu and Sen, Abhijit (2005), 'Poverty and Inequality in India: Getting Closer to the Truth' in Angus Deaton and Valerie Kozel (eds.), The Great Indian Poverty Debate, New Delhi, Macmillan.

Kapur, Devesh (2002), 'The Causes and Consequences of India's IT Boom', India Review, 1, 91-110.

Khilnani, Sunil (1998), The Idea of India, New York, Farrar, Straus and Giroux.

Kochar, Kalpana, Kumar, Utsav, Rajan, Raghuram, Subramanian, Arvind and Tokatlidis, Ioannis (2006), 'India's Pattern of Development: What Happened, What Follows', IMF Working Paper WP/06/22.

Kohli, Atul (2006a), 'Politics of Economic Growth in India, 1980-2005, Part I: The 1980s' Economic and Political Weekly, April 1, 1251-1259.

Kohli, Atul (2006b), 'Politics of Economic Growth in India, 1980-2005: Part II: The 1990s and Beyond', Economic and Political Weekly, April 8, 1361-1370.

Lancaster, Geoffrey and Ray, Ranjan (2005), 'On Setting the Poverty Line, Based on Nutrient Prices', Economic and Political Weekly, January 1, 46-56.

Majumdar, Mukul (1997), 'The East Asian Miracle and India', The Asiatic Society, Monograph, Calcutta, 1-51.

Mathur, K. B. L. (2004), 'The Growth Rate Mystery', Economic and Political Weekly, July 17, 3228-3231. 
Murthy, N.R. Narayana (2004), 'The Impact of Economic Reforms on Industry in India: A Case Study of the Software Industry', in Kaushik Basu (ed.), India's Emerging Economy: Performance and Prospects in the 1990s and Beyond, Cambridge MA, MIT Press and New Delhi, Oxford University Press.

Panagariya, Arvind (2004), 'Growth and Reforms during 1980s and 1990s', Economic and Political Weekly, June 19, 2581-2594.

Rakshit, Mihir (2007), 'Oil Price Shocks,' in Basu (2007a).

Ramesh, Jairam (2005), Making sense of Chindia: Reflections on China and India, New Delhi, India Research Press.

Rao, D. Tripati (2007), 'Do Savings, Investment and Interest Rates Respond to Each Other?' in G. S. Ganesh Prasad (ed.), Transformation, Transition or Stagnation?

Chennai: Madras Institute of Development Studies.

Rodrik, Dani and Subramanian, Arvind (2004a), 'Why India Can Grow at 7 Per Cent a Year and More: Projections and Reflections', Economic and Political Weekly, April 17, 1591-1596.

Rodrik, Dani and Subramanian, Arvind (2004b), 'From 'Hindu Growth' to Productivity Surge: The Mystery of the Indian Growth Transition', IMF Working Paper No. WP/04/77.

Rodrik, Dani, Subramanian, Arvind and Francesco Trebbi (2002), 'Institutions Rule: The Primacy of Institutions over Geography and Integration in Economic Development', NBER Working Paper 9305, National Bureau of Economic Research, Washington.

Sen, Amartya (2004), 'Democracy and Secularism in India' in Kaushik Basu (ed.), India's Emerging Economy: Performance and Prospects in the 1990s and Beyond, Cambridge MA, MIT Press and New Delhi, Oxford University Press.

Shetty, S. L. (2007), 'India's Savings Performance since the Advent of Planning,' in K. L. Krishna and A. Vaidyanathan (eds.), Institutions and Markets in India's Development, New Delhi: Oxford University Press.

Shome, Parthasarathi (2007), 'Savings and Investment,' in Basu (2007a).

Srinivasan, T.N. (2000), Eight Lectures on India's Economic Reforms, New Delhi, Oxford University Press.

Srinivasan, T.N. (2005), 'Comments on "From 'Hindu Growth' to Productivity Surge: The Mystery of the Indian Growth Transition”,' IMF Staff Papers, vol. 52, No. 2.

Srinivasan, T.N. and Tendulkar, S. (2003), Reintegrating India with the World Economy, Washington, Institute for International Economics.

Subramanian, A. (2006), 'Growth Experience', in Basu (2007a). 
Subramanian, S. (2006), Rights, Deprivation and Poverty: Essays in Concepts and Measurement, New Delhi, Oxford University Press.

Unel, B., 2003, "Productivity Trends in India's Manufacturing Sectors in the Last Two Decades," IMF Working Paper, WP/03/22, (Washington: International Monetary Fund).

Vaidyanathan, A. (2006). 'Farmers' Suicides and the Agrarian Crisis' Economic and Political Weekly, September 23, 4009-4013.

Varshney, Ashutosh (2007), 'India's Democratic Challenge,' Foreign Affairs, vol. 86, 93106.

Virmani, Arvind (2004a) 'India's Economic Growth: From Socialist Rate of Growth to Bharatiya Rate of Growth', Working Paper No. 122, Indian Council for Research on International Economic Relations, New Delhi

Virmani, Arvind (2004b), 'Sources of India's economic growth: Trends in Total Factor Productivity', Working Paper No. 131, Indian Council for Research on International Economic Relations, New Delhi.

Wallack, J. S. (2003), 'Structural Breaks in Indian Macroeconomic Data', Economic and Political Weekly, October 11, 4312-4315.

Williamson, John and Zagha, Roberto (2002), 'From Slow Growth to Slow Reform', Institute for International Economics, Washington.

World Bank (2006), 'India’s Employment Challenge', Work in Progress, World Bank, Washington. 